University of Nebraska - Lincoln

DigitalCommons@University of Nebraska - Lincoln

Faculty Publications: Department of Entomology

January 2004

\title{
Atrazine induction of a family 4 cytochrome P450 gene in Chironomus tentans (Diptera: Chironomidae)
}

\author{
Diana K. Londono \\ University of Nebraska-Lincoln \\ Blair D. Siegfried \\ University of Nebraska-Lincoln, bsiegfried1@ufl.edu \\ Michael J. Lydy \\ Southern Illinois University, Carbondale, IL
}

Follow this and additional works at: https://digitalcommons.unl.edu/entomologyfacpub

Part of the Entomology Commons

Londono, Diana K.; Siegfried, Blair D.; and Lydy, Michael J., "Atrazine induction of a family 4 cytochrome P450 gene in Chironomus tentans (Diptera: Chironomidae)" (2004). Faculty Publications: Department of Entomology. 69.

https://digitalcommons.unl.edu/entomologyfacpub/69

This Article is brought to you for free and open access by the Entomology, Department of at DigitalCommons@University of Nebraska - Lincoln. It has been accepted for inclusion in Faculty Publications: Department of Entomology by an authorized administrator of DigitalCommons@University of Nebraska - Lincoln. 
Published in Chemosphere 56 (2004), pp. 701-706. doi: 10.1016/j.chemosphere.2003.12.001

Copyright (C) 2003 Elsevier Ltd. Used by permission. http://www.sciencedirect.com/science/journal/00456535

Submitted June 26, 2003; revised November 13, 2003; accepted 1 December 2003.

\title{
Atrazine induction of a family 4 cytochrome P450 gene in Chironomus tentans (Diptera: Chironomidae)
}

\author{
Diana K. Londoño ${ }^{1}$, Blair D. Siegfried ${ }^{1, *}$, and Michael J. Lydy ${ }^{2}$ \\ ${ }^{1}$ Department of Entomology, University of Nebraska-Lincoln, 202 Plant Industry Bldg., Lincoln, NE 68583-0816, USA \\ ${ }^{2}$ Department of Zoology, Fisheries and Illinois Aquaculture Center, Southern Illinois University, Carbondale, IL 62901, USA \\ * Corresponding author-B. D. Siegfried: tel 402 472-8714; fax 402 472-4687; email: bsiegfried1@unl.edu
}

\begin{abstract}
Cytochrome P450-dependent microsomal monooxygenase (P450) activity was measured in control and atrazine-exposed third instar midge larvae, Chironomus tentans. Significantly elevated $O$-demethylase activity was observed in gut homogenates taken from midges exposed to atrazine concentrations from 1 to $10 \mathrm{ppm}$ for $90 \mathrm{~h}$. No significant induction was observed at atrazine concentrations below $1 \mathrm{ppm}$. A region of a cytochrome P450 family 4 gene was amplified and sequenced from C. tentans larvae. Alignments of inferred amino acid sequences with other insect CYP4 gene homologues indicate a high degree of similarity. Northern blot analysis employing the CYP4 gene fragment as a probe showed an overexpression in C. tentans exposed to atrazine. The results support the previously identified inducibility of cytochrome P450-dependent activity and provide insight into the potential consequences of atrazine exposure to aquatic organisms.
\end{abstract}

Keywords: Herbicide, Aquatic contamination, Cytochrome P450, CYP4, Aquatic insects, Monooxygenase

\section{Introduction}

Cytochrome P450-dependent microsomal monooxygenases represent the single most important enzyme system involved in the detoxification of xenobiotics and have been detected in virtually all organisms examined from bacteria to mammals. In insects, this system is important in regulating levels of endogenous compounds such as hormones, fatty acids and steroids, as well as in the biotransformation of xenobiotics such as pesticides (Scott, 1999). P450 enzymes are also found in the biosynthetic pathways of ecdysteroids and juvenile hormones, which are central to insect growth, development, and reproduction (Feyereisen, 1999).

Cytochrome $\mathrm{P} 450$ represents an inducible enzyme system, and increased amounts of specific P450 isozymes are observed after exposure of organisms to a variety of organic chemicals
(Scott, 1999). Several major classes of environmental contaminants induce the cytochrome P450 system (Hoffman et al., 1995). Cytochrome P450 enzymes are inducible through a mechanism that is controlled at the transcriptional level (Batar et al., 1997). The net result of enzyme induction is an increase in enzyme activity. The ecological and physiological significance of induction is uncertain, although with insects, induction is believed to provide versatility in the adaptation of insects to their environment (Terriere, 1984).

Some of the most common pollutants in Midwestern US lakes and streams include agriculture herbicides from the triazine group such as atrazine (2-chloro-4-ethylamino-6-isopropylamino-1,3,5-triazine). Atrazine is used for control of broadleaf weeds in several major US grain crops. It is one of the most extensively used herbicides in North America, and has been detected in both surface water and groundwater 
(Gruessner and Watzin, 1996). Studies of its occurrence and behavior in streams and rivers draining agricultural lands have shown that the highest atrazine concentrations usually occur in relatively brief pulses following rain events, especially those that occur soon after herbicide application (DeNoyelles et al., 1982). However, significant effects of atrazine at ecologically relevant concentrations have been reported to cause hermaphroditism and demasculinization in male frogs exposed to 0.1 and $1.0 \mu \mathrm{g} / \mathrm{l}$ of atrazine (Hayes et al., 2002).

Recently, several studies have shown that in larvae of the aquatic midge, Chironomus tentans (Fabricius), simultaneous exposure to atrazine and selected organophosphate insecticides caused greater than additive toxicity (Pape-Lindstrom and Lydy, 1997; Belden and Lydy, 2000; Jin-Clark et al., 2000). Body residue analysis of midges exposed in vivo to atrazine and chlorpyrifos mixtures indicated that chlorpyrifos was biotransformed more rapidly in atrazine-treated midges compared to unexposed controls. Additionally, in vivo biotransformation of chlorpyrifos in treated and control midges indicated that an increase in the toxic metabolite (chlopyrifos$O$-analog) was generated in atrazine-exposed midges (Belden and Lydy, 2000). We have also measured the effect of atrazine exposure on cytochrome P450-dependent monooxygenase activity (aldrin epoxidase) and have found increased activity as a result of atrazine exposure (10 ppm) (Miota et al., 2000). A 45-kDa protein of increased intensity was observed after SDS-PAGE of microsomal protein that is similar in size to cytochrome P450 enzymes reported for other insects. Heme staining of SDS-PAGE gels and immunochemical studies using a Drosophila melanogaster anti-P450 polyclonal antiserum further support the cytochrome $\mathrm{P} 450$ nature of this inducible 45-kDa protein.

Although a biochemical understanding of atrazine induction of P450 enzymes in C. tentans and its potential for synergism with other toxins is emerging, there is nothing presently known regarding the specific $\mathrm{P} 450$ forms involved in this induction. Identification of specific atrazine-inducible P450 genes could enhance sensitivity of detection and provide insight into potential consequences of exposure. The objectives of present research were to: (1) optimize conditions for measuring induction of $C$. tentans P450-dependent activity; and, (2) identify specific P450 genes involved in this process and measure their responsiveness to atrazine exposure.

\section{Materials and methods}

\subsection{Atrazine exposure}

Experiments were initiated by adding $50 \mathrm{C}$. tentans (third instar) to each of 3 replicate 1 liter glass beakers with 1000 $\mathrm{ml}$ of moderately hard water. C. tentans larvae were obtained from Wichita State University, Department of Biological Sciences, and were maintained according to US EPA protocols (US Environmental Protection Agency, 1993). Due to the cannibalistic nature of $C$. tentans, approximately 2 $\mathrm{cm}$ of sand was added to each beaker to facilitate burrowing. Exposures were held at room temperature under a $16 \mathrm{~h}$ light $/ 8 \mathrm{~h}$ dark photoperiod. Midges were allowed to acclimate to exposure water for $24 \mathrm{~h}$ prior to the addition of the atrazine. Atrazine (99\% purity, Chem Service, West Chester, PA, USA) was delivered to the water using $1 \mathrm{ml}$ of ethyl acetate $(0.001,0.01,0.1,1,10 \mathrm{mg} / \mathrm{l})$. Each experiment was performed in triplicate, consisting of one ethyl acetate control and three atrazine experimental beakers. After $90 \mathrm{~h}$ of exposure, midges were collected from each beaker for cytochrome P450 activity measurement.

\subsection{Protein preparation}

Gut tissue was dissected from $C$. tentans larvae by excising the head, thorax, and last two abdominal segments. The guts were pulled from the carcass and homogenates of 40 guts were prepared in $0.5 \mathrm{ml}$ of $0.15 \mathrm{M}$ potassium phosphate buffer (pH 7.4), 1 mM EDTA, and 10\% glycerol, with a teflon glass Potter-Elvehjem type homogenizer (Scott and Liu, 1996). Homogenates were centrifuged at $10,000 \mathrm{~g}$ for 20 min, and the supernatant removed for use in enzyme assays. Protein concentration for all preparations was measured with a commercially available bicinchoninic acid protein assay (Pierce, Rockford, IL) adapted for microtitre plates according to manufacturer instructions, with bovine serum albumin as the standard.

\subsection{Cytochrome P450 activity measurements}

Cytochrome P450 functional activity was measured using 7-methoxyresorufin as a substrate, which has previously been shown to be relatively specific for inducible cytochrome P450 in both mice and insects (Rodrigues and Prough, 1991). Reaction mixes for both substrates included $2 \mu \mathrm{l}$ of substrate $(0.5$ $\mathrm{mM}$ in ethanol), $40 \mu \mathrm{l}$ of $10,000 \mathrm{~g}$ supernatant from gut homogentes $(0.5-1 \mathrm{mg}), 143 \mu \mathrm{l}$ of $0.1 \mathrm{M}$ sodium phosphate $(\mathrm{pH}$ 7.8), $0.1 \mathrm{mM}$ EDTA and $5 \mathrm{mM}$ magnesium chloride. After a $1 \mathrm{~min}$ pre-incubation at $31^{\circ} \mathrm{C}, 10 \mu \mathrm{l}$ of NADPH $(2 \mathrm{mg} / \mathrm{ml}$ in buffer) was added, and the reaction recorded for $10 \mathrm{~min}$. Activity was measured in a 96-well fluorescent plate reader (Fluoroskan Ascent FL Series, Labsystems; Helsinki, Finland). Methoxyresorufin $O$-demethylation was measured directly as the increase in resorufin fluorescence. Wavelength and slit settings were $530 \mathrm{~nm}, 4-\mathrm{nm}$ slit (excitation) and $580 \mathrm{~nm}, 0.5$ $\mathrm{nm}$ slit (emission) for resorufin. A standard methoxyresorufin curve was used to quantify specific $O$-demethylase activity (Mayer et al, 1977). 
Significant differences in $C$. tentans $O$-demethylase activity among atrazine concentrations were determined by analysis of variance (PROC GLM; SAS Institute, 1999). Differences among treatment means were determined with the Fisher protected least significant difference (LSD) at the 5\% level of significance (SAS Institute, 1999).

\subsection{Amplification of genomic DNA by polymerase chain reac- tion (PCR)}

Genomic DNA was isolated from 10 atrazine-exposed $C$. tentans whole bodies by homogenization in $0.025 \mathrm{mM} \mathrm{NaCl}$, $0.005 \mathrm{mM}$ EDTA, $0.05 \mathrm{mM}$ Tris, $\mathrm{pH}$ 7.5, 1\% SDS. The homogenate was then treated with $10 \mathrm{mg} / \mathrm{ml}$ of proteinase $\mathrm{K}$ (Sigma Chemical Co., Los Angeles, CA) at $65^{\circ} \mathrm{C}$ for $30 \mathrm{~min}$ and $10 \mathrm{mg} / \mathrm{ml}$ of Rnase A (Sigma) followed by incubation at $37{ }^{\circ} \mathrm{C}$ for $1 \mathrm{~h}$. Two phenol:chloroform (50:50) extractions (Sambrok et al., 1989) were performed followed by ethanol precipitation, and DNA pellets were resuspended in $20 \mu \mathrm{l}$ of Tris-EDTA ( $\mathrm{pH}$ 8.0). Partially degenerate polymerase chain reaction (PCR) primers were designed from the family 4-specific primers reported by Snyder et al. (1995) and biased toward the published mosquito (Anopheles albimanus) sequence for a family 4-specific gene (Scott et al., 1994). Forward and reverse primers, corresponding to the $i$-helix and heme-binding regions of family 4 cytochrome $\mathrm{P} 450 \mathrm{~s}$, respectively, were used 5'-GAG GTI GAC ACI TTC ATG TTC GAA GGI CAC GAC AC-3' and 5'-CTG ICC GAT GCA GTT ICG CGG ICC IGC CIT GAA CGG-3'. Amplification of genomic DNA was accomplish by the following program: $\left(75^{\circ} \mathrm{C}\right.$ for $2 \mathrm{~min}, 94$ ${ }^{\circ} \mathrm{C}$ for $2 \mathrm{~min}, 35$ cycles of $94{ }^{\circ} \mathrm{C}$ for $1 \mathrm{~min}, 45^{\circ} \mathrm{C}$ for $2 \mathrm{~min}$, and $72{ }^{\circ} \mathrm{C}$ for $3 \mathrm{~min}$, followed by $75^{\circ} \mathrm{C}$ extension for $5 \mathrm{~min}$ ) in a $50 \mu \mathrm{l}$ reaction containing $50 \mathrm{mM} \mathrm{KCl}, 10 \mathrm{mM}$ Tris- $\mathrm{HCl}$ (pH 8.3), $2.5 \mathrm{mM} \mathrm{MgCl}, 0.2 \mathrm{mM}$ dNTPs, $0.001 \%$ gelatin, 0.2 $\mu \mathrm{g}$ of each oligonucleotide, 2.5 units of Amplitaq DNA polymerase (Applied Biosystems; Foster City, CA), and $1.6 \mu \mathrm{g}$ of genomic DNA. Following amplification, PCR products were separated on a $1 \%$ low-melt agarose gel (Biotech grade). Amplification products were visualized by ethidium bromide staining, and three bands ranging in size from 250 to 700 bp were obtained. The three products of approximately 250 , 444 and $700 \mathrm{bp}$ were excised from the gel and purified using a Sephaglass Band Prep Kit (Amersham Pharmacia Biotech; Piscataway, NJ). A total of seven PCR replicates were conducted, and products reamplified using the same reaction conditions, PCR program, visualization and isolation as previously described.

Purified fragments were sequenced in both directions at the Iowa State University DNA Sequencing Laboratory in Ames, IA. Sequence confirmation and amino acid translations were performed using the GCG10 software package (Genetics Computer Group; Madison, WI).

\subsection{Northern blotting}

A single PCR amplification product of 444 bp corresponding to a cytochrome P450 family 4 gene fragment from $C$. tentans was randomly labeled with digoxigenin-conjugated dUTP using a DIG High Prime Labeling Kit (Roche Biochemical; Mannheim, Germany). Total RNA was isolated from the $C$. tentans larvae exposed to 0 and $10 \mathrm{ppm}$ of atrazine using the Qiagen Rneasy kit (Valencia, CA). For all experiments, similar concentrations of $10 \mu \mathrm{g} / \mu \mathrm{l}$ and $260 / 280$ $\mathrm{nm}$ absorbance ratios $>1.8$ were used. RNA was affixed to nylon membranes (Zeta-Probe; Bio-Rad, Hercules, CA) by capillary transfer following denaturing formaldehyde agarose electrophoresis (Herrin and Schmidt, 1988). Standardized loadings were confirmed prior to probe hybridization by methylene blue staining intensity directly on nylon membranes (Stegeman and Livingstone, 1998). Hybridization occurred over night at $45{ }^{\circ} \mathrm{C}$ followed by two reduced stringency washes in SSC and $0.1 \%$ SDS at room temperature with a final wash at $65{ }^{\circ} \mathrm{C}$ under constant agitation. Luminescent detection was accomplished using a DIG High Prime Detection Kit (Roche). Densitometric scanning was accomplished using a Gel-Doc 2001 interfaced with Quantity One software (Bio-Rad).

\section{Results}

\subsection{Atrazine induction of methoxyresorufin O-demethylase}

Aqueous exposure of midges to $0.001,0.01$, and $0.1 \mathrm{mg} / 1$ of atrazine for $90 \mathrm{~h}$ did not result in significant induction $(P>$ 0.05 ) of cytochrome P450 dependent $O$-demethylase activity in Chironomus tentans gut homogenates (Figure 1). In contrast, exposure of midges to 1.0 and $10 \mathrm{mg} / 1$ atrazine resulted caused significant induction of $O$-demethylase activity $(P<$ 0.05 ) (1.5- and 3.9-fold respectively) relative to the control or unexposed midges (Figure 1).

\subsection{Cytochrome P450 amplification (family 4)}

Of the three products obtained from degenerate PCR, only the $444 \mathrm{bp}$ product exhibited a nucleotide sequence similar to cytochrome P450 family 4 genes. The sequences obtained (accession number AY155456) share two regions of signature motifs, $\mathbf{E} \sim \mathbf{T} \sim \mathbf{L} \sim \mathbf{R}$, and $\mathbf{P} \sim \mathbf{D} \sim \mathbf{K} \sim \mathbf{F}$ (Figure 2), corresponding to cytochrome $\mathrm{P} 450$ family 4 genes. These regions contain amino acids highly conserved with other members of 
the CYP4 family in insects. A BLASTx search of Genbank using the $C$. tentans cytochrome $\mathrm{P} 450$ nucleotide sequence identified five insect cytochrome $\mathrm{P} 450$ genes that shared optimal translated protein homology: Helicoverpa armigera (Lepidoptera: Noctuidae) CYP4G8 with $74 \%$ of identity, Diabrotica virgifera virgifera (Coleoptera: Chrysomelidae) CYP4G18 with $77 \%$ of identity, and Drosophila melanogaster (Diptera: Drosophilidae) CYP-4G1 with $81 \%$ of identity (Genbank). Alignments of the inferred amino acid sequences (excluding primer regions) of the three CYP4 gene fragments including the CYP450 for $C$. tentans indicate the presence high degree of similarity among the sequences (Figure 2).

\subsection{Determination of cytochrome P450 family 4 expression}

Northern blotting experiments employed a probe derived from the cytochrome P450 fragment previously identified. Two different bands of 1.6 and $1.9 \mathrm{~kb}$ RNA hybridized with the probe in both exposed and unexposed samples from third instar Chironomus tentans larvae (Figure 3). Constitutive signals

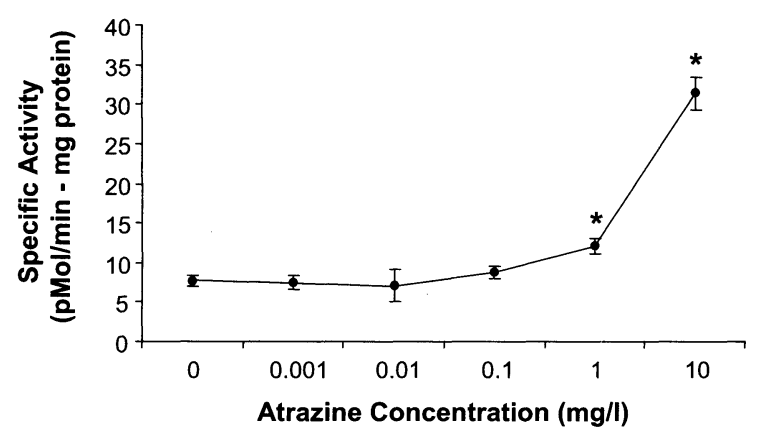

Figure 1. Effect of atrazine on NADPH-dependent cytochrome P450 O-demethylation in the $10,000 \mathrm{~g}$ supernatant of gut homogenates from $C$. tentans late instar larvae. Bars indicate means \pm SD of 3 replicate experiments with 3 measurements for each experiment; * indicates significant differences $(P<$ 0.05 ) from control or unexposed midges. were more intense for atrazine exposed relative to unexposed midges suggesting that cytochrome P450 family 4 gene expression was induced by atrazine. The presence of two distinct bands suggests the presence of multiple genes and indicates that at least two subfamilies of cytochrome P450 family 4 genes may be induced by atrazine.

\section{Discussion}

Results from this study suggest that a cytochrome P450 family 4 gene is induced by atrazine in third instar Chironomus tentans larvae. Exposure of midge larvae to 1.0 and 10 $\mathrm{mg} / \mathrm{l}$ atrazine resulted in significantly increased cytochrome P450 activity relative to unexposed midges. Concentrations below $1.0 \mathrm{mg} / \mathrm{l}$ did not cause significant induction, and atrazine concentrations that caused induction are greater than those commonly reported in contaminated surface water. Given that cytochrome P450 plays a significant role in regulating growth and developmental hormones in both vertebrates and invertebrates, and due to its primary function in xenobiotic metabolism, environmental contaminants that influence its activity could result in important ecological effects.

Family 4 P450 genes have been identified in numerous insect species, including Anopheles albimanus (Rodrigues and Prough, 1991), Manduca sexta (Snyder et al., 1995), Drosophila melanogaster (Danielson et al., 1998), Diabrotica virgifera virgifera (Scharf et al., 2001) and Musca domestica (Rodrigues and Prough, 1991). Family 4 P450 genes are increasingly being identified as important in conferring resistance to insecticides and other environmental chemicals, and have also been implicated in toxin metabolism (Rodrigues and Prough, 1991). Although amplification with primers designed from family 4 P450 genes resulted in a single product,

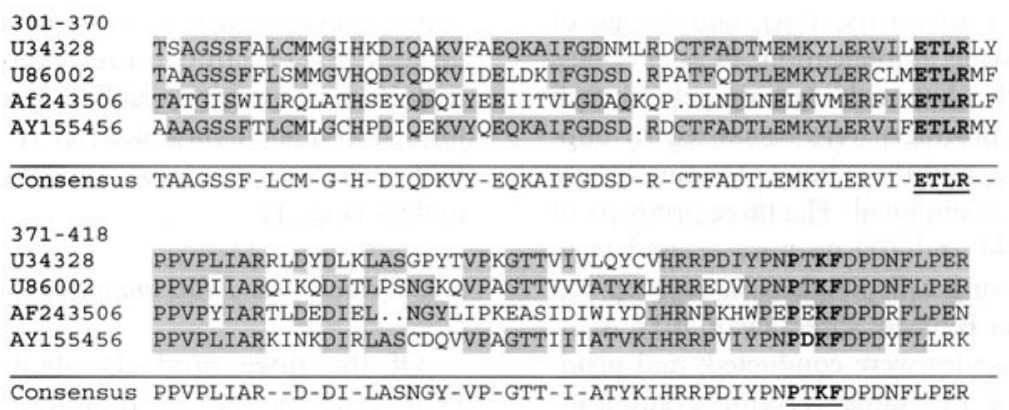

Figure 2. Alignment of deduced amino acids for C. tentans CYP4 gene fragment (AY155456) with three homologous CYP4 fragments from Drosophila melanogaster (U34328), H. armigera (U86002) and D. virgifera virgifera (AF243506). Consensus sequence is provided at bottom (blackened residues are identical to consensus; periods = consensus). Hyphens indicate gaps inserted by GCG-pileup program for alignment purposes. The conserved motifs ETLR and PTKF are underlined. 
northern analysis indicates that there may be at least two distinct family 4 Cytochrome $\mathrm{P} 450$ genes that are induced in $C$. tentans.

Although atrazine concentrations that caused significant induction of P450 activity in C. tentans were generally higher than what is considered to be environmentally relevant, the identification of specific $\mathrm{P} 450$ genes responsive to atrazine could provide the basis for developing more sensitive and specific molecular biomarkers that can be used in evaluation and protection of water quality. Additionally, because this enzyme system plays a critical role in numerous physiological processes, its induction measured at a molecular scale provides necessary genetic information to assess potential consequences of exposure in aquatic organisms.

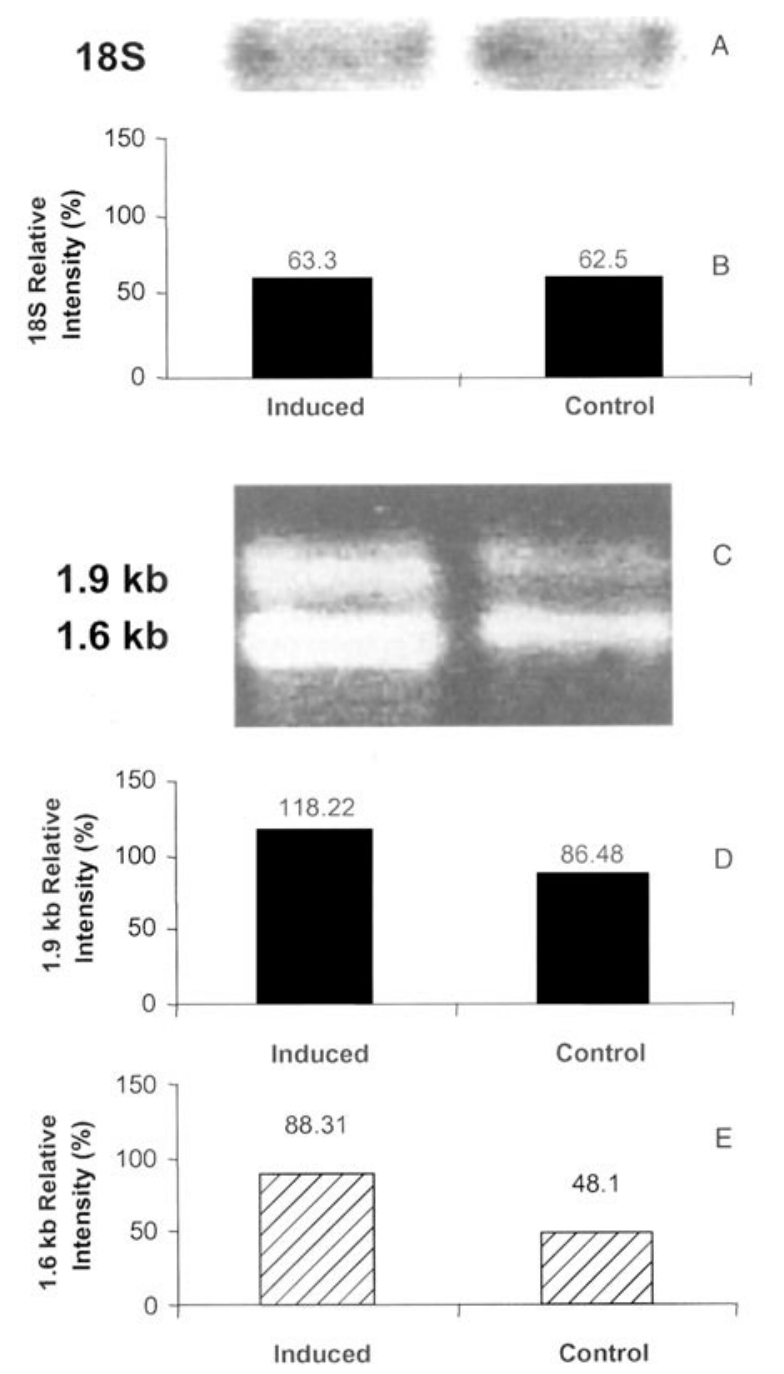

Figure 3. Northern blotting analysis of CYP4 expression in atrazine induced (exposed $10 \mathrm{mg} / \mathrm{l}$ atrazine in solution for $90 \mathrm{~h}$ ) and control C. tentans larvae. (A) Methylene blue-stained 18S RNA on membrane prior to northern hybridization. (B) Densitometric analysis corresponding to staining intensity shown in (A). (C) Chemiluminescence indicating probe hybridization to 1.9 and 1.6 kb mRNA bands. (D) and (E) Densitometric analysis corresponding to 1.9 and $1.6 \mathrm{~kb}$ mRNA bands, respectively. The blot is representative of 5 separate experiments.

\section{Acknowledgements}

The authors wish to acknowledge Michael Sharf and Srinivas Parimi who contributed with their suggestions and assistance. David Taylor and Meg Allen provided critical review. Rafael Montalvo provided support for the molecular biology procedures. Terence Spencer assisted in maintenance of the midge cultures. This project was supported by a grant from the US EPA EPSCoR program (grant \#R827590-01-0). This paper is published with approval of the Director as Journal Series paper 14147. Nebraska Agricultural Research Division, and contribution number 1157 of the Department of Entomology, University of Nebraska.

\section{References}

Batar, M., Schalk, M.A., Pierrel, A., Zimmerlin, F.D., Werck-Reichhart, D., 1997. Regulation of the cinnamate 4-hydrolase (CYP73AI) in Jerusalem artichoke tubers in response to wounding and chemical treatments. Plant Physiol. 113, 951-959.

Belden, J.B., Lydy, M.J., 2000. Impact of atrazine on organophosphate insecticide toxicity. Environ. Tox. Chem. 19 (9), 2266-2274.

Danielson, P.B., Foster, J.L., McMahill, M.M., Smith, M.K., Fogleman, J.C., 1998. Induction by alkaloids and phenobarbital of family 4 cytochrome P450s in Drosophila: evidence for involvement in host plant utilization. Mol. Gen. Genet. 259, 54-59.

DeNoyelles, F.W., Kettle, D., Sinn, D.E., 1982. The responses of plankton communities in experimental ponds to atrazine, the most heavily used pesticide in the United States. Ecology 63, 1285-1293.

Feyereisen, R., 1999. Insect P450 enzymes. Ann. Rev. Entomol. 44, 507-533.

Gruessner, B., Watzin, M.C., 1996. Response of aquatic communities from a Vermont stream to environmentally realistic atrazine exposure in laboratory microcosms. Environ. Tox. Chem. 15, $410-419$.

Hayes, T.B., Collins, A., Lee, M., Mendoza, M., Noriega, N., Stuart, A., Vonk, A., 2002. Proc. Nat. Acad. Sci. 99 (8), 5476-5480.

Herrin, D.L., Schmidt, G.W., 1988. Rapid, reversible staining of northern blots prior to hybridization. Biotechniques 6, 196-200.

Hoffman, D.J., Rattne, B.A., Burton Jr., G.A., Cairns Jr., J., 1995. Handbook of Ecotoxicology. Lewis Publishers, Boca Raton.

Jin-Clark, Y., Lydy, M.J., Zhu, K.Y., 2000. Effects of atrazine and cyanazine on chlorpyrifos toxicity in Chironomus tentans. (Diptera: Chironomidae). Environ. Tox. Chem. 21, 598-603.

Mayer, R.T., Jermyn, J.W., Burke, M.D., Russell, A.P., 1977. Methoxyresorufin as a substrate for the fluorometric assay of insect microsomal O-dealkylases. Pestic. Biochem. Physiol. 7, 349-354.

Miota, F., Siegfried, B.D., Scharf, M.E., Lydy, M., 2000. Atrazine induction of cytochrome $\mathrm{P} 450$ in C. tentans larvae. Chemosphere 40, 285-291.

Pape-Lindstrom, P.A., Lydy, M.J., 1997. Synergistic toxicity of atrazine and organophosphate insecticides contravenes the response addition mixture model. Environ. Tox. Chem. 16, 2415-2420.

Rodrigues, A.D., Prough, R.A., 1991. Induction of cytochrome 
P450IA1 and P450IA2 and measurement of catalytic activities. Meth. Enzymol. 206, 423-431.

Sambrok, J.E., Fritsch, F., Maniatis, T., 1989. Molecular cloning: A Laboratory Manual, Second ed. Cold Spring Harbor Laboratory Press, Cold Spring Harbor, NY.

SAS Institute, 1999. SAS OnlineDoc, version 8.01. SAS Institute, Cary, NC.

Scharf, M.E., Parimi, S., Meinke, L.J., Chandler, L.D., Siegfried, B.D., 2001. Expression and induction of three family 4 cytochrome P450 (CYP4) genes identified from insecticide-resistant and susceptible western corn rootworms, Diabrotica virgifera virgifera. Insect. Mol. Biol. 10, 139-146.

Scott, J.A., Collins, F.H., Feyereisen, R., 1994. Diversity of cytochrome P450 genes in the mosquito. Anopheles Albimanus. Biochem. Biomed. Biophys. Res. Commmun. 205, 1452-1459.

Scott, J.G., Liu, N., 1996. Genetic analysis of factors controlling high-level expression of cytochrome P450, CYP6D1, cytochrome $\mathrm{b}_{5}, \mathrm{P} 450$ reductase, and monooxygenase activities in LPR house flies, Musca domestica. Biochem. Genet. 34, 133-1147.

Scott, J.G., 1999. Cytochromes P450 and insecticide resistance. Insect. Biochem. Mol. Biol. 29, 757-777.

Snyder, M.J., Stevens, J.L., Andersen, J.F., Feyereisen, R., 1995. Expression of cytochrome P450 genes of the CYP4 family in midgut and fat body of the tobacco hornworm, Manduca sexta. Arch. Biochem. Biophys. 321, 13-20.

Stegeman, J.J., Livingstone, D.R., 1998. Forms and functions of cytochrome P450. Compos. Biochem. Physiol. 212, 1-3.

Terriere, L., 1984. Induction of detoxification enzymes. Ann. Rev. Entomol. 29, 71-88.

US Environmental Protection Agency, 1993. Standard operating procedures for laboratory cultures of Chironomus tentans. Duluth, MN: US EPA Office of Research and Development. ERL-D-SOP-CTI-015.
Diana Londoño is a Ph.D. candidate at the University of NebraskaLincoln. She received her B.S. from University of Los Andes (Bogata, Colombia) and her M.S. from the University of Nebraska-Lincoln. Her dissertation research focuses on the molecular characterization of cytochrome $\mathrm{P} 450$ induction in aquatic organisms.

Michael Lydy is an Assistant Professor in the Department of Zoology at Southern Illinois University. He received his B.S. in Chemistry from Wittenberg University in 1984, an M.S. in Zoology in 1986 from Miami University (Ohio), and a Ph.D. in Zoology from the Ohio State University in 1990. His research interests include sediment toxicology, bioavailability, toxicokinetics, biomonitoring and the study of chemical mixtures.

Blair Siegfried is a Professor of Entomology at the University of Nebraska-Lincoln. He received his B.S. in Biology from Lock Haven University in 1981, an M.S. in Entomology from the University of Florida in 1984, and his Ph.D. in Entomology from The Pennsylvania State University in 1989. His research interests center on biochemical adaptations that insects use to tolerate exposure to xenobiotics. 